\title{
ORGANISASI LUAR SEKOLAH UNTUK PENINGKATAN KARAKTER (STUDI KASUS DI IPNU IPPNU RANTING NGRECO KOTA KEDIRI)
}

\author{
${ }^{1}$ Agus Miftakus Surur, ${ }^{2}$ Aullia Rahmawati \\ Alamat: Rejomulyo, Jl. Sunan Ampel No.7, Ngronggo, \\ Kec. Kota Kediri, Kediri, Jawa Timur 64127 \\ Email: 1Surur.math@gmail.com,2Auliar@gmail.com
}

DOI: $10.29313 /$ tjpi.v7i1.3395

Accepted: January 10th, 2018. Approved: July 16th, 2018. Published: July 16th, 2018

\begin{abstract}
In exposure, research results contain the task and analysis on the role of school organization in the formation of character as well as how organizations in the creation of the character of teenagers so good character, noble character, as well as ethical sublime. Positive activities organized by Executive Board members, the characters can be formed. The activities of community members become entwined and creating togetherness. Furthermore, in the activity-there are also IPPNU IPNU activities prayer in congregation and completing the Qur' an that is religious. It can foster the religious nature of the members. Organizational behavior is defined as the study of human behavior in organizations that use the science about how buman beings act in organizations. This organizational behavior basing on analysis of the buman at going so belpful to others.
\end{abstract}

Keywords: Organization, overseas schools, characters, and IPNU IPPNU

\section{ABSTRAK}

Dalam pemaparan hasil penelitian berisikan pendiskripsian dan analisis mengenai peran organisasi luar sekolah dalam pembentukan karakter serta cara organisasi dalam pembentukan karakter remaja agar berkarakter baik, berakblak mulia, serta berbudi pekerti lubur. Kegiatan-kegiatan positifyang diselenggarakan oleh pengurus, karakter anggota dapat terbentuk. Kegiatan tersebut kebersaaman antar anggota menjadi terjalin dan terciptalah ukhuah. Selain itu dalam kegiatan IPNU-IPPNU juga terdapat kegiatan sholat berjamaah dan khataman Qur'an yang bersifat keagamaan. Hal ini dapat menumbubkan kerelegiusan anggota. Perilaku keorganisasian di definisikean sebagai studi mengenai perilaku manusia dalam organisasi yang menggunakan ilmu pengetabuan tentang bagaimana manusia bertindak dalam organisasi. Perilaku organisasi ini mendasarkan pada analisis terhadap manusia yang di tujukan bagi ke manfaatan orang.

Kata Kunci: Organisasi, Luar Sekolah, Karakter, dan IPNU IPPNU. 


\section{PENDAHULUAN}

Menurut David Elkind dan Freddy Sweet Ph. D., pendidikan karakter adalah usaha sengaja (sadar) untuk membantu manusia memahami, peduli dan melaksanakan nilai-nilai etika inti (Zubaidi, 2012: 15). Pendidikan karakter dipahami sebagai upaya penanaman kecerdasan dalam berfikir, penghayatan dalam bentuk sikap, dan pengalaman dalam bentuk perilaku yang sesuai dengan nilai-nilai luhur yang menjadi jati dirinya, diwujudkan dalam interaksi dengan Tuhan-Nya, diri sendiri, antar sesama, dan lingkungannya. Nilai-nilai luhur tersebut antara lain: kejujuran, kemandirian, sopan santun, kemuliaan sosial, kecerdasan berfikir termasuk berfikir logis (Zubaidi, 2012: 17).

Pendidikan karakter memiliki 3 fungsi utama. Pertama, fungsi pembentukan dan pengembangan potensi. Agar berfikir baik, berhati baik, dan berperilaku baik sesuai dengan falsafah hidup pancasila. Kedua, fungsi perbaikan dan penguatan keluarga, satuan pendidikan, masyarakat, dan pemerintah untuk ikut berpartisipasi dan bertanggung jawab dalam pengembangan potensi warga negara dan pembangunan bangsa menuju bangsa yang maju, mandiri dan sejahtera. Ketiga, fungsi penyaring memilah budaya bangsa sendiri dan menyaring budaya bangsa lain yang tidak sesuai dengan nilai-nilai budaya dan karakter bangsa yang bermartabat (Zubaidi, 2012: 18).

Hakikat organisasi bukan hanya merupakan alat untuk menyediakan peralatan, berupa barang dan jasa, melainkan juga menciptakan lingkungan tempat kehidupan manusia yang berhubungan dengan setiap aspek kehidupan. Organisasi dapat memengaruhi perilaku manusia dan sebaliknya, perilaku manusia dapat mengubah organisasi. Akan tetapi, manusia jarang memperhatikan dan tidak menyadari adanya pengaruh psikologis dari setiap jenis keterlibatan organisasi terhadap unsur individu dan kelompok, serta masyarakat, juga berpengaruh pada kondisi suatu negara bangsa, bahkan membentuk suatu kebiasaan menjadi kebudayaan.

Proses pembentukan kebudayaan melalui sebuah organisasi dapat berjalan dengan disadari ataupun tidak disadari. Jika tidak disadari, dapat dikatakan organisasi itu sangat kuat memengaruhi pembentukan perilaku manusia didalamnya (Tampubolon, 2008: 2).

Karakter merupakan perwujudan berupa perilaku yang menggambarkan sifat ataupun cerminan diri seseorang. Oleh sebab itu, karakter sangatlah perlu diciptakan dan dibentuk guna membentuk pribadi yang baik. Jika karakter seseorang buruk, maka buruk pula sifat dan perilakunya begitu pula sebaliknya (Tampubolon, 2008: 2). Misalnya, jika di rumah atau lingkungan masyarakat karakter seseorang tidak terbentuk secara baik maka di masyarakat mempermasalahkan hal tersebut sehingga menjadi bahan omongan ataupun ejekan. Dalam hal ini sekolah juga ikut berperan serta dalam rangka pembentukan karakter. Karena sekolah merupakan wadah siswa dalam menimba ilmu salah satunya akhlak dan etika. Akan tetapi, sekolah tidak bisa secara total dapat membentuk karakter siswa, oleh sebab itu perlunya media yang secara utuh untuk dapat membentuk karakter siswa dengan adanya organisasi dan ekstrakurikuler.

Dengan adanya organisasi baik di sekolah maupun di masyarakat, karakter remaja dapat dibentuk agar menjadi lebih baik melalui kegiatan-kegiatannya. Begitu halnya dengan IPNU-IPPNU ranting Desa 
Ngreco yang mana salah satu tujuan didirikan yaitu untuk membentuk karakter para remaja.

Pendidikan karakter merupakan sebuah istilah yang semakin hari semakin mendapatkan pengakuan dari masyarakat Indonesia saat ini. Terlebih dengan dirasakannya berbagai ketimpangan hasil pendidikan dilihat dari perilaku lulusan pendidikan formal saat ini, misalnya korupsi, perkembangan seks bebas pada kalangan remaja, narkoba, tawuran, pembunuhan, perampokan oleh pelajar dan pengangguran lulusan sekolah menengah ke atas. Semuanya terasa lebih buruk ketika negara ini dilanda krisis dan tidak kunjung beranjak dari krisis yang dialami (Kesuma, 2012: 4).

Dalam kaitannya dengan pendidikan akhlak, terlihat bahwa pendidikan karakter mempunyai orientasi, yaitu pembentukan karakter. Pendidikan karakter telah berhasil dirumuskan oleh para penglihatnya sampai pada tahapan yang sangat operasional meliputi metode, strategi, dan teknik, sedangkan pendidikan akhlak syarat dengan informasi kriteria ideal dan sumber karakter baik (Zubaidi, 2012: 65).

Akhlak diartikan sebagai ilmu tata krama, ilmu yang berusaha mengenal tingkah laku manusia kemudian memberi nilai kepada perbuatan baik atau buruk sesuai dengan norma-norma dan tata susila. Menurut Al-Ghazali akhlak adalah suatu perangai (watak/tabiat) yang menetap dalam jiwa seseorang dan merupakan sumber timbulnya perbuatan-perbuatan tertentu dari dirinya secara mudah dan ringan tanpa difikirkan atau direncanakan sebelumnya (Zubaidi, 2012: 67).

Perilaku keorganisasian didefinisikan sebagai studi mengenai perilaku manusia dalam organisasi yang menggunakan ilmu pengetahuan tentang bagaimana manusia bertindak dalam organisasi. Elemen utama dari perilaku keorganisasian adalah orang, struktur, teknologi, dan lingkungan (Tampubolon, 2008: 3).

Hasil observasi yang dilakukan peneliti menunjukan bahwa dari organisasi luar sekolah yang diikuti oleh Ninda dan Nanda memberikan dampak positif. Melalui organisasi, mereka dapat belajar menjadi seseorang yang bertanggung jawab dengan sesuatu yang sedang dilakukannya, dapat mengatur waktu antar organisasi, sekolah dan rumah. Karena pada dasarnya mereka memiliki posisi penting dalam sebuah organisasi tersebut yaitu Ninda sebagai ketua dan Nanda sebagai sekertaris, dan posisi tersebut merupakan salah satu sentral dalam sebuah organisasi.

Dengan padatnya kegiatan yang dilakukan oleh mereka, mereka masih bisa melaksanakan kegiatan sekolah dengan baik, hubungan sosial yang diciptakan oleh mereka juga sangat baik, akhlak yang dimiliki mereka juga terjaga karena pada dasarnya organisasi yang diikuti mereka berhubungan dengan agama. Jadi dapat disimpulkan, melalui organisasi yang mereka ikuti dapat membentuk karakter yang berupa akhlak yang baik.

Dengan mengikuti organisasi luar sekolah serta aktif dalam setiap kegiatannya, diharapkan remaja-remaja dapat terbentuk karakter yang baik serta luhur. Oleh sebabnya penulis tertarik untuk mengamati mengenai "Pembentukan Karakter melalui Organisasi Luar Sekolah" di IPNU-IPPNU ranting Ngreco- Kediri.

\section{METODOLOGI PENELITIAN}

Metode adalah cara yang digunakan untuk melaksanakan suatu pekerjaan agar tercapai sesuai dengan yang dikehendaki. 
Sehingga metode penelitian adalah cara yang digunakan dalam penelitian supaya penelitian akan menghasilkan sesuatu yang telah diprediksikan sebelumnya. Pemilihan metode yang tepat sangat penting karena berhubungan dengan aktifitas peneliti di lapangan dari awal sampai memperoleh kesimpulan (Surur, 2017: 110).

Pendekatan yang dilakukan dalam penelitian ini menggunakan pendekatan kulitatif. Pendekatan kualitatif yaitu pendekatan dalam penelitian yang berorientasi pada gejala-gejala yang bersifat alamiah (naturalistik) serta tidak dapat dilakukan di laboratorium melainkan harus terjun di lapangan. Begitu halnya dengan objek serta judul yang diambil oleh peneliti yang mana berupa gejala-gejala yang bersifat alamiah yaitu karakter yang terbentuk secara alami melalui kagiatan organisasi luar sekolah. Penelitian yang dilakukan peneliti pun harus terjun lagsung ke lapangan untuk melakukan pengamatan dan mendapatkan sumber data (Wikipedia, 2017).

Jenis penelitian yang dilakukan peneliti adalah penelitian studi kasus, dengan objek penelitiannya adalah IPNU-IPPNU Ranting Ngreco. Dalam pemaparan hasil penelitian mengenai "Pembentukan Karakter melalui Organisasi Luar Sekolah" ini sendiri berisikan pendiskripsian dan analisis mengenai peran organisasi luar sekolah dalam pembentukan karakter serta cara organisasi dalam pembentukan karakter remaja agar berkarakter baik, berakhlak mulia, serta berbudi pekerti luhur. Dari uraian hasil penelitian, menunjukkan ciri-ciri bahwasaya penelitain ini merupakan jenis penelitian studi kasus.

Lokasi penelitian yang diambil yaitu di area taman MAN Kediri 1 yang mana tempat untuk wawancara peneliti dengan narasumber (Nanda dan Ninda). Selain itu, peneliti melakukan wawancara kembali di rumah guna mendapatkan data tambahan sekaligus melakukan pengamatan secara langsung dalam kehidupan sehari-hari. Sedangkan lokasi kegiatan organisasi yang dijadikan peneliti sebagai lokasi penelitian yaitu ketika kegiatan khataman Qur'an yang dilaksanakan di salah satu rumah pengurus yang bernama saudari Sindu dan kegiatan kumpulan pengurus yang dilaksanakan juga di salah satu rumah pengurus yaitu saudara Rizal.

Sumber data dari penelitian ini didapat dengan menggunakan alat berupa wawancara, observasi dan dokumentasi, dengan uraian sebagai berikut:

Dalam penelitian ini wawancara dilakukan untuk menemukan permasalahan yang nantinya dijadikan sebagai studi pendahuluan dan juga untuk mengetahui mengenai tingkat responden. Wawancara ini dilakukan kepada ketua organisasi yang bernama Ninda Dwi Fitria dan juga Nanda Dwi Ftriana selaku sekretaris. Sedangkan pertanyaan yang diajukan ketika wawancara yaitu seputar kegiatan organisasi, perilaku, peran organisasi dalam pembentukan karakter, serta mengenai bagaimana dukungan masyarakat mengenai pembentukan karakter melalui organisasi luar sekolah ini.

Dalam penelitian ini, observasi dilakukan dengan cara terjun langsung ke tempat objek penelitian yaitu ketika kegiatan khataman Qur'an yang diadakan oleh IPNUIPPNU ranting Ngreco, dan juga ketika kegiatan rutinan pengurus IPNU-IPPNU ranting Ngreco. Hal tersebut dilakukan guna dapat mengamati secara langsung bagaimana kegiatan organisasi berlangsung, serta bagaimana proses pembentukan karakter melalui kegiatan organisasi. Selain itu peneliti 
juga terjun ke kediaman narasumber untuk mengetahui kegiatan keseharian narasumber. Untuk disekolahnya sendiri, peneliti melakukan observasi ke sekolah sekaligus melakukan wawancara, namun observasi untuk kegiatan ekstra kurikuler sendiri tidak ada.

Dokumentasi yang diambil adalah data primer dan data sekunder, yang mana data primer berupa foto kegiatan khataman Qur'an, kegiatan wawancara yang berupa foto dan audio wawancara, dan juga foto kegiatan kumpulan pengurus. Sedangkan data sekunder berupa foto kegiatan karnaval dalam rangka memperingati hari kemerdekaan yang dilaksanakan pada bulan Agustus lalu.

Adapun foto atau dokumentasi selain organisasi yaitu kegiatan keseharian rumah seperti bersih-bersih (didapat dengan cara primer) dan foto kegiatan sekolah yaitu berupa foto pada saat kegiatan pementasan teater berupa foto Nanda dan Ninda yang berperan dalam teater (diambil dengan cara sekunder). Seluruh dokumentasi tersebut nantinya akan dijadikan sebagai sumber data dan juga sebagai data pendukung dalam analisis data.

Pengumpulan data dapat dilakukan dalam berbagai setting, berbagai sumber, dan berbagai cara. Bila dilihat dari setting-nya, data penelitian ini dikumpulkan pada setting lembaga organisasi, yaitu organisasi luar sekolah IPNU-IPPNU. Bila dilihat dari sumber datanya, pengumpulan datanya dengan menggunakan sumber primer yang mana sumber data tersebut dicari dan didapat oleh peneliti. Selanjutnya bila dilihat dari segi cara atau teknik pengumpulan data, yaitu dengan teknik pengumpulan data dengan melakukan wawancara (interview), observasi, dan dokumentasi, dengan uraian sebagai berikut:
Wawancara digunakan sebagai teknik pengumpulan data apabila peneliti ingin melakukan studi pendahuluan untuk menemukan permasalahan yang harus diteliti, dan juga apabila peneliti ingin mengetahui hal-hal dari responden yang lebih mendalam dan jumlah respondennya sedikit/kecil (Sugiyono, 2014: 194).

Dalam penelitian ini sediri wawancara dilakukan dengan melontarkan beberapa bertanyaan kepada narasumber yaitu ketua organisasi (Ninda) dan juga sekertaris organisasi (Nanda) dengan tujuan menentukan permasalahan dan juga kejelasan dari permasalahan yang diteliti.

Sebelum melakukan wawancara, peneliti terlebih dahulu membuat janji dengan Nanda dan Ninda untuk melakukan wawancara dan menentukan lokasi untuk wawancara. Lokasi wawancara yang dipilih yaitu di area taman MAN 1 KEDIRI, hal ini karena narasumber masih duduk di madrasah aliyah yaitu di MAN 1 KEDIRI. Untuk pelaksanaan wawancara sendiri dilakukan ketika narasumber pulang sekolah yaitu pukul 16.00-17.00, hal ini karena adanya waktu luang narasumber ketika pulang sekolah.

Teknik pengumpulan data dengan observasi digunakan bila penelitian berkenaan dengan perilaku manusia, proses kerja, gejala-gejala alam dan bila responden yang diamati tidak terlalu besar (Sugiyono, 2014: 203).

Observasi disini, dilakukan dengan cara terjun langsung ke lokasi yaitu di area taman MAN 1 KEDIRI untuk melakukan wawancara, hal ini dilakukan guna dapat mengetahui keseharian narasumber. Selain itu peneliti juga terjun ke tempat tinggal narasumber guna mendapatkan data tambahan. Peneliti juga terjun ketika kegiatan organisasi, yaitu ketika kegiatan 
Khataman Qur'an dan kegiatan kumpulan pengurus. Peneliti juga terjun ke kediaman narasumber untuk mengetahui aktifitas narasumber. Hal ini dilakukan untuk mendapatkan kesesuaian antara data yang didapat dari wawancara dengan data lapangan.

Dokumentasi adalah salah satu metode/teknik pengumpulan data yang digunakan dalam metodologi penelitian sosial. Pada intinya metode dokumenter adalah metode atau teknik yang digunakan untuk menelusuri data historis (Bungin, 2005: 144).

Dokumentasi dilakukan untuk mendapatkan bukti dari data yang didapat, serta sebagai sumber data yang dapat dianalisis. Dokumentasi dalam penelitian ini sendiri berupa dokumentasi kegiatan wawacara dengan narasumber yaitu foto dan audio, dokumentasi kegiatan khataman Qur'an dan kegiatan kumpulan pengurus yang mana berupa foto, dan foto kegiatan di rumah seperti bersih-bersih. Adapun dokumentasi lain sebagai data tambahan yang bersifat sekunder, yaitu berupa foto kegiatan karnaval dalam rangka memperingati hari kemerdekaan nasional dan foto saat kegiatan sekolahan.

Merinci jawaban yang disampaikan dari narasumber, aktivitas dan dokumentasi, yang meliputi kegiatan organisasi, izin orang tua, ketidaksesuaian program kerja, upaya peyakinkan untuk mendapat dukungan masyarakat, kerja sama dalam melaksanakan kegiatan, apakah program kerja dilaksanakan dengan baik, kedisiplinan berupa datang tepat waktu, alasan keikut sertaan dalam berorganisasi, perubahan diri berupa pengaturan sekolah dan organisasi, malaksanakan tugas, keterbukaan, serta bagaimana menyelesaikan masalah.

Mengelompokkan jawaban yang disampaikan dari narasumber, aktifitas dan dokumentasi, yang meliputi: Kesimpulan sementara yang diambil dari reduksi data dan display data, yaitu. Jadi, kegiatan yang dilakukan oleh narasumber seperti izin orang tua, keterbukaan, pengaturan sekolah dan organisasi, membantu kegiatan, pengaturan sekolah dan organisasi, melaksanakan tugas, dan juga kerjasama menunjukan pada karakter narasumber. Kegiatan seperti dukungan masyarakat, upaya penyakinan, ketidaksesuaian menunjukan dalam organisasi. Kegiatan seperti alasan organisasi, perubahan diri, ketidaksesuaian menunjukan pada hal lain-lain.

Dari hasil dokumentasi yang didapat baik yang bersifat primer maupun sekunder, nantinya akan dijadikan sebagai alat sinkronisasi antara hasil wawancara dan observasi yang talah didapat dari narasumber yaitu wawancara dengan ketua IPPNU dan sekretaris IPPNU ranting Ngreco dan lokasi observasi, dengan data yang ada di lapangan yang sudah diambil melalui dokumentasi berupa foto dan audio.

Tabel 1. Indikator Karakter yang Dikembangkan dalam Organisasi

\begin{tabular}{llll}
\hline No & Karakter & Organisasi & Lain-lain \\
\hline 1 & Izin Orangtua & Dukungan Masyarakat & Ketidaksesuaian \\
\hline 2 & Keterbukaan & Ketidaksesuaian & Perubahan Diri \\
\hline 3 & $\begin{array}{l}\text { Pengaturan Sekolah dan } \\
\text { Organisasi }\end{array}$ & $\begin{array}{l}\text { Manfaat Kegiatan } \\
\text { Khataman Qur'an }\end{array}$ & Alasan Organisasi \\
\hline 4 & Membantu Kegiatan & $\begin{array}{l}\text { Tujuan Kegiatan } \\
\text { Cermin }\end{array}$ & \\
& & & \\
\hline
\end{tabular}




\begin{tabular}{lll}
\hline 5 & $\begin{array}{l}\text { Pengaturan Sekolah dan } \\
\text { Organisasi }\end{array}$ & $\begin{array}{l}\text { Waktu Pelantikan } \\
\text { Kepengurusan dan } \\
\text { Kegiatan Rutinan }\end{array}$ \\
\hline 6 & Melaksanakan Tugas & $\begin{array}{l}\text { Kegiatan Silaturahmi } \\
\text { Antar Ranting }\end{array}$ \\
\hline 7 & Kerjasama & $\begin{array}{l}\text { Kegiatan Rutinan dan } \\
\text { Musyawarah }\end{array}$ \\
\hline 8 & $\begin{array}{l}\text { Program } \\
\text { Dilaksanakan dengan } \\
\text { Baik }\end{array}$ & \\
\hline
\end{tabular}

\section{PEMBAHASAN}

Menurut David Elkind dan Freddy Sweet Ph. D., pendidikan karakter adalah usaha sengaja (sadar) untuk membantu manusia memahami, peduli dan melaksanakan nilai-nilai etika inti (Zubaidi, 2012: 15). Pendidikan karakter dipahami sebagai upaya penanaman kecerdasan dalam berfikir, penghayatan dalam bentuk sikap, dan pengalaman dalam bentuk perilaku yang sesuai dengan nilai-nilai luhur yang menjadi jati dirinya, diwujudkan dalam interaksi dengan Tuhan-Nya, diri sendiri, antar sesama, dan lingkungannya. Nilai-nilai luhur tersebut antara lain: kejujuran, kemandirian, sopan santun, kemuliaan sosial, kecerdasan berfikir termasuk berfikir logis (Zubaidi, 2012: 17).

Berdasarkan teori di atas dalam penelitian, peneliti menemukan bahwa setiap organisasi pastilah mempunyai visi, misi maupun program kerja yang sudah dirancang oleh pengurus dan juga anggota dari organisasi tersebut, tetapi dalam penelitian ini menemukan setiap rencana atau rancangan yang telah tersusun terkadang tidak berjalan dengan semestinya, hal ini tentunya juga terjadi di organisasi IPNUIPPNU ranting Ngreco. Untuk menanggapi hal tersebut anggota organisasi IPNUIPPNU ranting Ngreco melakukan musyawarah dan berembuk dalam kegiatan kumpulan pengurus untuk melakukan evaluasi kegiatan, yang kemudian menjadikan permasalahan tersebut sebagai cerminan dan evaluasi agar kegiatan selanjutnya tidak terulang. Tidak terlaksananya beberapa program kerja yang telah dirancang dikarenakan pengurus menangani terlebih dahulu tugas anggota lain, sehingga agenda atau jadwal kegiatan menjadi tertunda dan bahkan ada yang tidak terlaksana, bisa dikatakan terjadi penumpukan agenda.

Pendidikan karakter memiliki 3 fungsi utama. Pertama, fungsi pembentukan dan pengembangan potensi. Agar berfikir baik, berhati baik, dan berperilaku baik sesuai dengan falsafah hidup pancasila. Setelah cukup lama narasumber mengikuti organisasi IPNU-IPPNU, narasumber merasakan mendapatkan hal positif diantaranya, adalah narasumber mendapat pengalaman baru dan positif serta percaya diri narasumber menjadi terasah melalui kegiatan-kegiatan yang diselenggarakan.

Kedua, fungsi perbaikan dan penguatan keluarga, satuan pendidikan, masyarakat, dan pemerintah untuk ikut berpartisipasi dan bertanggung jawab dalam pengembangan potensi warga negara dan pembangunan bangsa menuju bangsa yang maju, mandiri dan sejahtera. Proses pembentukan kebudayaan melalui sebuah organisasi dapat berjalan dengan disadari ataupun tidak disadari. Jika tidak disadari, dapat dikatakan organisasi itu sangat kuat memengaruhi pembentukan perilaku manusia didalamnya (Tampubolon, 2008: 2).

Dari masyarakat sekitar sangat mendukung dengan diadakannya kegiatan organisasi IPNU-IPPNU ranting Ngreco. Hal ini ditunjukkan dengan keikutsertaan masyarakat dalam kegiatan IPNU-IPPNU ranting Ngreco seperti khataman, selain itu 
masyarakat juga bersedia menyediakan tempat untuk kegiatan IPNU-IPPNU ranting Ngreco seperti kegiatan Khataman dan kumpulan pengurus. Setiap kegiatan yang diadakan oleh organisasi IPNU-IPPNU ranting Ngreco dilaksanakan di lingkungan masyarakat, hal ini dikarenakan agar anggota dan masyarakat dapat menjangkau dan ikut serta dalam pelasanakaan kegiatan.

Untuk terus mendapatkan dukungan dari masyarakat, anggota organisasi IPNUIPPNU ranting Ngreco membaur di masyarakat sekaligus meyakinkan masyarakat jika kegiatan yang diselenggarakan oleh organisasi IPNU-IPPNU ranting Ngreco bernilai positif. Selain itu, setiap pelaksanaan kegiatan organisasi IPNU-IPPNU ranting Ngreco setiap anggota tidak lupa untuk meminta izin orang tua. Hal ini perlu, karena hal demikian cukup berdampak bagi organisasi.

Ketiga, fungsi penyaring memilah budaya bangsa sendiri dan menyaring budaya bangsa lain yang tidak sesuai dengan nilainilai budaya dan karakter bangsa yang bermartabat (Tampubolon, 2008: 18).

Hakikat organisasi bukan hanya merupakan alat untuk menyediakan peralatan, berupa barang dan jasa, melainkan juga menciptakan lingkungan tempat kehidupan manusia yang berhubungan dengan setiap aspek kehidupan. Organisasi dapat memengaruhi perilaku manusia dan sebaliknya, perilaku manusia dapat mengubah organisasi. Akan tetapi, manusia jarang memperhatikan dan tidak menyadari adanya pengaruh psikologis dari setiap jenis keterlibatan organisasi terhadap unsur individu dan kelompok, serta masyarakat, juga berpengaruh pada kondisi suatu negara bangsa, bahkan membentuk suatu kebiasaan menjadi kebudayaan.

Proses pembentukan kebudayaan melalui sebuah organisasi dapat berjalan dengan disadari ataupun tidak disadari. Jika tidak disadari, dapat dikatakan organisasi itu sangat kuat memengaruhi pembentukan perilaku manusia di dalamnya (Tampubolon, 2008: 2).
Keikutsertaan narasumber di organisasi IPNU-IPPNU ranting Ngreco ini sendiri dikarenakan kemauan narasumber sendiri yang didasari ketertarikan dengan kegiatan-kegiatan yang diselenggarakan oleh organisasi IPNU-IPPNU ranting Ngreco, seperti kegiatan karnaval, khataman, dan kumpulan, namun kegiatan yang paling disenangi oleh narasumber yaitu kegiatan cermin, yang mana kegiatan ini berupa kritik saran yang dilakukan dan diberikan oleh seluruh anggota.

Meskipun narasumber sudah cukup lama mengikuti organisasi dan mendapatkan hal positif berupa pembentukan karakter, narsumber mengaku masih belum sepenuhnya menjalankan tugasnya dengan baik selaku ketua (Ninda) maupun sekertaris (Nanda). Hal ini dikarenakan narasumber merasa belum berpengalaman. Narasumber merasa belum bisa membagi waktu antara sekolah dengan organisasi dengan sekolah. Narasumber mengaku lebih mementingkan kegiatan organisasi IPNU-IPPNU ranting Ngreco ketimbang kegiatan sekolah. Hal ini dikarenakan, menurut narasumber kegiatan organisasi IPNU-IPPNU ranting Ngreco lebih menarik dibandingkan dengan kegiatan yang ada di sekolah.

Nanda dan Ninda serta anggota yang lain terkadang tidak datang tepat waktu bahkan tidak hadir, hal ini dikarenakan kesibukan masing-masing terutama kesibukan sekolah berupa tugas sekolah yang membuat beberapa anggota tidak dapat datang ke tempat kegiatan. Namun meski demikian narasumber berusaha dan ikut serta dalam menyelesaikan masalah yang terjadi diorganisasi yang diikutinya.

Hakikat organisasi bukan hanya merupakan alat untuk menyediakan peralatan, berupa barang dan jasa, melainkan juga menciptakan lingkungan tempat kehidupan manusia yang berhubungan dengan setiap aspek kehidupan. Organisasi dapat memengaruhi perilaku manusia dan sebaliknya, perilaku manusia dapat mengubah organisasi. Akan tetapi, manusia jarang memperhatikan dan tidak menyadari 
adanya pengaruh psikologis dari setiap jenis keterlibatan organisasi terhadap unsur individu dan kelompok, serta masyarakat, juga berpengaruh pada kondisi suatu negara bangsa, bahkan membentuk suatu kebiasaan menjadi kebudayaan.

Proses pembentukan kebudayaan melalui sebuah organisasi dapat berjalan dengan disadari ataupun tidak disadari. Jika tidak disadari, dapat dikatakan organisasi itu sangat kuat memengaruhi pembentukan perilaku manusia di dalamnya (Tampubolon, 2008: 2).

Dalam pelaksanaan tugas masingmasing anggota sendiri lebih sering dikerjakan sendiri-sendiri, hal ini dikarenakan dalam organisasi IPNU-IPPNU ranting Ngreco terdapat prosedur yang mana baik dalam pelaksanaan tugas maupun jika terjadi kendala dalam pelaksanaan tugas, anggota terlebih dahulu menyelesaikan masalah tersebut, namun jika dari anggota tidak mampu untuk mengatasi baru pengurus turun tangan untuk membantu. $\mathrm{Hal}$ ini menunjukkan adanya pembangunan karakter kemandirian yang tengah diasah. Namun, terkadang anggota yang keberatan dalam menjalankan tugas meminta bantuan kepada anggota lain untuk memabantu, hal ini menunjukkan kekompakan yang tumbuh dalam organisasi IPNU-IPPNU ranting Ngreco.

Organisasi IPNU-IPPNU ranting Ngreco juga menjalin kerjasama dengan organisasi lain, salah satunya organisasi IPNU-IPPNU ranting lain untuk menjalin silaturrahmi dan menjalin kerjasama dalam hal kegiatan.

IPNU-IPPNU ranting Ngreco merupakan salah satu organisasi luar sekolah yang cukup berperan dalam pembentukan karakter. Karakter terbentuk melalui kegiatan-kegiatan yang diselenggarakan oleh pengurus, salah satunya khataman, karnaval, dan kumpulan pengurus.

Dalam pembentukan sebuah karakter seseorang itu bisa mendapatkan dari mana saja, tidak hanya dari guru yang mengajar setiap hari, bisa jadi keluarga dan lingkungan sekitar.

Setelah mengikuti organisasi ini diharapkan narasumber menjadi orang yang berguna bagi nusa dan bangsa. Dampak narasumber mengikuti organisasi PNUIPPNU ini ketika di rumah ialah mulailah muncul rasa kedewasaannya karena sebelumnya dia mendapat amanah sebagai ketua dan satunya menjadi sekretaris. Rasa tanggung jawab mulai tumbuh dan ketika di rumah narasumber mengetahui yang harus dilakukan meskipun tanpa disuruh ibunya maupun keluarganya. Sedangkan ketika di sekolah narasumber ini tumbuh menjadi sosok yang bijaksana dan kreatif di dalam kelas. Karena bertambahnya pengalaman dari organisasi yang diikutinya.

\section{KESIMPULAN}

Organisasi IPNU-IPPNU Ranting Ngreco sangat berperan dalam pembentukan karakter. Melalui kegiatan-kegiatan yang diusung seperti rutinan, kumpulan, khataman, dan lain-lain, karakter anggota dapat terbentuk. Dari penelitian lapangan ditemukan, bahwasanya anggota dapat menjalin kerjasama yang baik antar anggota yaitu berupa saling membantu dalam menjalankan tugas yang berat, menyelesaikan masalah bersama-sama, tanggung jawab dengan tugas yang diterimanya, serta anggota juga memiliki jiwa kepemimpinan berkat jabatan yang diembannya. Hakikat organisasi bukan hanya merupakan alat untuk menyediakan peralatan, berupa barang dan jasa, melainkan juga menciptakan lingkungan tempat kehidupan manusia yang berhubungan dengan setiap aspek kehidupan. Organisasi dapat memengaruhi perilaku manusia dan sebaliknya, perilaku manusia dapat mengubah organisasi. Akan tetapi, manusia jarang memperhatikan dan tidak menyadari adanya pengaruh psikologis dari setiap jenis keterlibatan organisasi terhadap unsur individu dan kelompok, serta masyarakat, juga berpengaruh pada kondisi suatu negara 
bangsa, bahkan membentuk suatu kebiasaan menjadi kebudayaan.

Dari data yang didapat, Nanda dan Ninda belum sepenuhnya mampu menjalankan tugas dan tanggung jawab yang diembannya, serta tidak selalu disiplin saat datang ke kegiatan. Namun meski demikian, Nanda dan Ninda mengaku setelah mengikuti organisasi tersebut merasa memiliki karakter lebih baik dari sebelumnyan. Pasalnya, sebelum mengikuti organisasi Nanda dan Ninda adalah anak yang pemalu, tidak percaya diri, dan belum cukup dewasa dalam menyelesaikan tugas. Namun, setelah mengikuti organisasi IPNUIPPNU tersebut Nanda dan Ninda merasa lebih percaya diri, lebih mampu menyelesaikan tugas atau masalah, serta mereka merasa tanggung jawab mereka terasah melalui tugas yang mereka terima.

Melalui kegiatan-kegiatan positif yang diselenggarakan oleh pengurus, karakter anggota dapat terbentuk. Mislanya, dalam kegiatan rutinan anggota, anggota dan pengurus berkumpul, shearing dan bertukar argumen. Melalui kegiatan tersebut kebersaaman antar anggota menjadi terjalin dan terciptalah ukhuah. Selain itu dalam kegiatan IPNU-IPPNU juga terdapat kegiatan sholat berjamaah dan khataman Qur'an yang bersifat keagamaan. Hal ini dapat menumbuhkan kerelegiusan anggota yang mana menjadikan anggota lebih mendekatkan diri kepada Tuhan Yang Maha Esa. Perilaku keorganisasian didefinisikan sebagai studi mengenai perilaku manusia dalam organisasi yang menggunakan ilmu pengetahuan tentang bagaimana manusia bertindak dalam organisasi. Perilaku organisasi ini mendasarkan pada analisis terhadap manusia yang ditujukan bagi kemanfaatan orang. Elemen utama dari perilaku keorganisasian adalah orang, struktur, teknologi, dan lingkungan. Lingkungan organisasi juga dapat dilihat dari dua sudut pandang, yaitu lingkungan eksternal dan lingkungan internal.

\section{DAFTAR PUSTAKA}

Bungin, Burhan. (2005). Metode Penelitian Kuantitatif (Komunikatif, Ekonomi, dan Kebijakan Publik Serta Ilmu-ilmu Sosial Lainnya. Jakarta: Prenada Media

Kesuma, Dharma, Dkk. (2012). Pendidikan Karakter "Kajian Teori Dan Praktik Di Sekolah”. Bandung: Remaja Rosdakarya

Sugiyono. (2014). Metode Penelitian Pendidikan (Pendekatan Kuantitatif, Kualitataif, dan R\&D). Bandung: Alfabeta

Surur, Agus Miftakus. (2017). Formasi 4-1-5 Penakbluk Masalab (Studi Kasus: Penulisan Karya Tulis Ilmiah Proposal Skripsi STAIN Kediri 2017). Prosiding Seminar Nasional PPKn III. Universitas Muhammadiyah Ponorogo

Tampubolon, Manahan P. (2008). Perilaku Keorganisasian (Organization Behavior) Prespektif Organisasi Bisnis. Bogor: Ghalia Indonesia

Wikipedia, http://id.m.wikipedia.org/wiki/Pen elitian_kualitatif. Diakses pada tanggal 20 Nopember 2017 pukul 16:03.

Zubaidi. (2012). Desain Pendidikan Karakter: "Konsepsi Dan Aplikasinya Dalam Lembaga Pendidikan”. Jakarta: Prenada Media. 